\title{
ADDITIONAL REFERENCES TO THE BEAN LACE BUG
}

\author{
By M. D. LEONARD,
}

Entomologist, Insular Experiment Station, Río Piedras, P. R.

In the Journal of the Department of Agriculture of Porto Rico 15(3) : 309-323 there was published a paper by M. D. Leonard and A. S. Mills entitled "Observations on the bean lace-bug in Porto Rico". A bibliography of 44 titles was included which was intended to be as complete an index as possible to Corythucha gossypii Fab. in literature. Mr. S. C. Bruner, Chief of the Department of Phytopathology of the Cuban Agricultural Experiment Station has been good enough to call our attention to several references which we overlooked. They are as follows:

Anonymous (presumably J. R. Johnston). El insecto que ataca la higuereta y modo de combatirlo. Rev. Agr. Com. y Trab. (Cuba) 1(10) : 531-533, 2 figs. October, 1918.

An offeial report by the Comision de Sanidad Vegetal (now Seccion de Sanidad Vegetal) on $C$. gossypii as a pest of the castor oil plant, control experiments are included; the adult is figured and spraying operations are shown in a photograph; nicotine sulfate and soap were used successfully.

Barthe, A. E. Cultivo industrial de la higuereta, Rev. Agr. Com. y

Trab. (Cuba) 2(3):93-95. March, 1919.

The secton relating to pests of the castor oil plant includes $C$. gossypii as an important pest; evidently largely compiled from previous work.

Bruner, S. C. Un honguillo parásito del Tingítido de la higuereta.

Rev. Agr. Com. y Trab. (Cuba) 2(5) : 218-219, May, 1919.

Relative to the fungus, Sporotrichum, parasitic on C. gossypii on the castor oil plant.

Bruner, S. C. Informe del departamento de entomología y fitopatología. Ejercicio de 1929 a 1930. Est. Exp. Agr. Cuba, p. 28. Mentioned as a lima bean pest.

Cardín, Patricio. Plagas de la higuereta en Cuba. Rev. Agr. Com. y Trab. (Cuba) 1(10):527-531. October, 1918.

Largely concerning the Corythucha, a serious pest of the castor oil plant; also lists the insect, in their order of being attacked, on: red pepper, soursop, peanut, kidney bean (frijol) squash, ramie and aguinaldo (Turbina corymbosa (L.) Raf.). 
Cardín, Patricio. Informe del departamento de entomología y patología de 1917 y 1918. Est. Exp. Agr. (Cuba) pp. 460-461. 1919.

In the report of the Department of Entomology experiments are mentioned for the control of $C$. gossypii on castor oil; soap is effective.

Mr. Bruner also writes that he has taken C. gossypii in small numbers on the leaves of banana in addition to some of the plants mentioned in the paper by Mr. Mills and myself. 